\title{
DEVELOPMENT OF MARITIME CONTAINER TRANSPORT IN SOUTHEAST ASIA
}

\begin{abstract}
The article presents the role of marine container transport in the present-day world economy, taking into consideration the position of China, Japan, South Korea and India in the global system of containerized cargo transport. Transshipments in the largest container ports of Asia in the period 1990-2016 are discussed. The container ship tonnage in China, Japan, South Korea and India is analyzed in the studied period. The main institutions financing the transport infrastructure development in the Europe-Asia transport corridors are described.

Keywords: maritime transport, container transport, transshipments in ports
\end{abstract}

\section{Introduction}

The maritime transport plays a very important role in the modern global economy, handling over $80 \%$ of the global trade volumes. Its carriage potential is very diverse in technical, technological, operational and freight type terms, whereby a wide variety of services can be provided, ranging from small cargoes of several hundred kilograms to large shipments of several hundred thousand kilograms.

Movement of cargo mass by sea has been revolutionized by containerization which has been introduced into transport and which in recent years has contributed to the transformation of vessels in terms of technology and design, changes in port areas, reduction of transport costs and manufacturing process globalization. Container ships which are among the youngest vessels in operation are successively rejuvenated. Newly built vessels have increasingly greater dimensions and their capacity is expanding as well (from 1250 TEUs in 1990 to more than 20000 TEUs in 2017). The latest and largest container ship, OOCL Hong Kong, built in South Korea in 2017 by Samsung Shipbuilding \& Heavy Industries Company Limited, 
with a DWT of 191422 can transport up to 21413 TEUs (vesselfinder, 2018). Owing to new technological solutions $\mathrm{CO}_{2}$ emissions per 1 TEU are expected to be reduced by $50 \%$ compared to the current average on the Asia-Europe route (Mindur, 2014).

Two basic types of vessels will be used in maritime container shipping, using the lo-lo vertical and ro-ro horizontal handling systems. These ships sail in the designated maritime corridors, also used by China, Japan, South Korea and India, whose share in the global foreign trade in goods is very substantial.

In 2016 , China had the largest share in the global exports $(13.5 \%$, compared to $13.8 \%$ in 2015). Japan took fourth place (after China, the United States and Germany) with a share of $4.1 \%$, and the fifth place was taken by South Korea $(3.4 \%)$ In terms of imports China came in second place following the United States (the value of goods imported to China was $10 \%$ of the value of global imports), and the $4^{\text {th }}$ place was taken by Japan $(3.8 \%)$ following Germany. South Korea $(2.8 \%)$ taking the $7^{\text {th }}$ place and India in the $12^{\text {th }}$ position $(2.3 \%)$ were also ranked among the world major importers. It is maritime transport that is commonly used for freight transport in these countries due to the geographical location (CSO, 2017).

\section{Container ports in China, Japan, South Korea and India}

Asian countries hold an important place in the global containerized freight system. Low costs of manufacture of goods in Asia and lower transport costs owing to the containerization are the reason why the ports of this region of the world dominate among the container transshipment tycoons. Table 1 shows the ranking of 10 largest container ports of Asia by shipping volume in the years 1980-2016 against the background of world ports.

The largest ports play the role of transshipment and logistics centres for ocean-going vessels (hubs), while smaller ports handling smaller container ships (feeders) provide feeder services for major ports. Thus, ships can reach a substantially greater number of ports located in a given region. Container ports are continuously dredged and upgraded with the use of automation and electronics to reduce the ship berthing time.

Table 1. Shipping volume in largest container ports of Asia in 1980-2016 (thousands of TEUs)

\begin{tabular}{|r|r|l|r|r|l|r|r|l|r|}
\hline $\begin{array}{c}\text { Rank } \\
\text { in Asia }\end{array}$ & $\begin{array}{r}\text { Rank } \\
\text { in the } \\
\text { world }\end{array}$ & Port & $\begin{array}{r}\text { Vol- } \\
\text { ume }\end{array}$ & $\begin{array}{r}\text { Rank } \\
\text { in the } \\
\text { world }\end{array}$ & Port & $\begin{array}{r}\text { Vol- } \\
\text { ume }\end{array}$ & $\begin{array}{c}\text { Rank } \\
\text { in the } \\
\text { world }\end{array}$ & Port & $\begin{array}{c}\text { Vol- } \\
\text { ume }\end{array}$ \\
\hline \multicolumn{7}{|c|}{1980} & \multicolumn{7}{|c|}{1985} \\
\hline 1 & 3 & Kobe & 14.7 & 3 & Hong Kong & 22.9 & 1 & Singapore & 52.2 \\
\hline 2 & 4 & Hong Kong & 14.7 & 4 & Kaohsiung & 19.0 & 2 & Hong Kong & 51.0 \\
\hline 3 & 5 & Kaohsiung & 98.0 & 5 & Kobe & 18.6 & 4 & Kaohsiung & 35.0 \\
\hline 4 & 6 & Singapore & 9.2 & 6 & Singapore & 17.0 & 5 & Kobe & 26.0 \\
\hline 5 & 12 & Yokohama & 7.2 & 7 & Yokohama & 13.3 & 6 & Busan & 23.5 \\
\hline 6 & 15 & Keelung & 6.6 & 11 & Keelung & 11.6 & 10 & Keelung & 18.3 \\
\hline 7 & 16 & Busan & 6.3 & 12 & Busan & 11.1 & 11 & Yokohama & 16.5 \\
\hline 8 & 18 & Tokyo & 6.3 & 14 & Tokyo & 10.0 & 13 & Tokyo & 15.6 \\
\hline
\end{tabular}




\begin{tabular}{|c|c|c|c|c|c|c|c|c|c|}
\hline $\begin{array}{l}\text { Rank } \\
\text { in Asia }\end{array}$ & $\begin{array}{l}\text { Rank } \\
\text { in the } \\
\text { world }\end{array}$ & Port & $\begin{array}{l}\text { Vol- } \\
\text { ume }\end{array}$ & $\begin{array}{l}\text { Rank } \\
\text { in the } \\
\text { world }\end{array}$ & Port & $\begin{array}{l}\text { Vol- } \\
\text { ume }\end{array}$ & $\begin{array}{l}\text { Rank } \\
\text { in the } \\
\text { world }\end{array}$ & Port & $\begin{array}{l}\text { Vol- } \\
\text { ume }\end{array}$ \\
\hline 9 & 19 & Jeddach & 5.6 & 21 & Jeddach & 6.8 & 20 & Manila & 10.4 \\
\hline 10 & 24 & Manila & 4.0 & 26 & Manila & 4.8 & 21 & Bangkok & 10.2 \\
\hline \multicolumn{4}{|c|}{2000} & \multicolumn{3}{|c|}{2005} & \multicolumn{3}{|c|}{2010} \\
\hline 1 & 1 & Hong Kong & 181.0 & 1 & Singapore & 231.9 & 1 & Shanghai & 290.7 \\
\hline 2 & 2 & Singapore & 170.4 & 2 & Hong Kong & 226.0 & 2 & Singapore & 284.3 \\
\hline 3 & 3 & Busan & 75.4 & 3 & Shanghai & 180.8 & 3 & Hong Kong & 237.0 \\
\hline 4 & 4 & Kaohsiung & 74.3 & 4 & Shenzhen & 162.0 & 4 & Shenzhen & 225.1 \\
\hline 5 & 6 & Shanghai & 56.1 & 5 & Busan & 118.4 & 5 & Busan & 141.9 \\
\hline 6 & 11 & Shenzhen & 40.0 & 6 & Kaohsiung & 94.7 & 6 & Ningbo & 131.4 \\
\hline 7 & 12 & Port Klang & 32.1 & 9 & Dubai & 76.2 & 7 & Guangzhou & 125.5 \\
\hline 8 & 13 & Dubai & 30.6 & 13 & Qindago & 63.1 & 8 & Qindago & 120.1 \\
\hline 9 & 15 & Tokyo & 29.0 & 14 & Port Klang & 57.2 & 9 & Dubai & 116.0 \\
\hline 10 & 19 & TJ Priok & 24.8 & 15 & Ningbo & 52.1 & 11 & Tjanjin & 100.8 \\
\hline \multicolumn{4}{|c|}{2011} & \multicolumn{3}{|c|}{2012} & \multicolumn{3}{|c|}{2013} \\
\hline 1 & 1 & Shanghai & 317.4 & 1 & Shanghai & 325.3 & 1 & Shanghai & 336.2 \\
\hline 2 & 2 & Singapore & 299.4 & 2 & Singapore & 316.5 & 2 & Singapore & 326.0 \\
\hline 3 & 3 & Hong Kong & 243.8 & 3 & Hong Kong & 231.2 & 3 & Shenzhen & 232.8 \\
\hline 4 & 4 & Shenzhen & 225.7 & 4 & Shenzhen & 229.4 & 4 & Hong Kong & 223.5 \\
\hline 5 & 5 & Busan & 161.8 & 5 & Busan & 170.4 & 5 & Busan & 176.9 \\
\hline 6 & 6 & Ningbo & 147.2 & 6 & Ningbo & 168.3 & 6 & Ningbo & 173.5 \\
\hline 7 & 7 & Guangzhou & 144.2 & 7 & Guangzhou & 147.4 & 7 & Qindago & 155.2 \\
\hline 8 & 8 & Qindago & 130.2 & 8 & Qindago & 145.0 & 8 & Guangzhou & 153.1 \\
\hline 9 & 9 & Dubai & 130.0 & 9 & Dubai & 133.0 & 9 & Dubai & 136.4 \\
\hline 10 & 10 & Tjanjin & 115.9 & 10 & Tjanjin & 123.0 & 10 & Tjanjin & 130.1 \\
\hline \multicolumn{4}{|c|}{2014} & \multicolumn{3}{|c|}{2015} & \multicolumn{3}{|c|}{2016} \\
\hline 1 & 1 & Shanghai & 352.9 & 1 & Shanghai & 365.4 & 1 & Shanghai & 371.3 \\
\hline 2 & 2 & Singapore & 338.7 & 2 & Singapore & 309.2 & 2 & Singapore & 309.0 \\
\hline 3 & 3 & Shenzhen & 240.3 & 3 & Shenzhen & 242.1 & 3 & Shenzhen & 239.8 \\
\hline 4 & 4 & Hong Kong & 222.3 & 4 & Ningbo & 206.3 & 4 & Ningbo & 215.6 \\
\hline 5 & 5 & Ningbo & 194.5 & 5 & Hong Kong & 200.7 & 5 & Hong Kong & 198.1 \\
\hline 6 & 6 & Busan & 186.9 & 6 & Busan & 194.7 & 6 & Busan & 194.6 \\
\hline 7 & 7 & Qindago & 165.8 & 7 & Guangzhou & 176.3 & 7 & Guangzhou & 188.6 \\
\hline 8 & 8 & Guangzhou & 163.9 & 8 & Qindago & 174.4 & 8 & Qindago & 180.5 \\
\hline 9 & 9 & Dubai & 152.5 & 9 & Dubai & 155.9 & 9 & Dubai & 147.7 \\
\hline 9 & 10 & Tjanjin & 140.6 & 10 & Tjanjin & 141.1 & 10 & Tjanjin & 146.0 \\
\hline
\end{tabular}

Source: (Hal, 2018)

At the present time, the largest container ports in the world are centres located mainly in China (Table 1). They have dominated, inter alia, the Japanese ports, including the largest Japanese port of Tokyo which was ranked among the world leaders still in 2000 (taking the $9^{\text {th }}$ position at that time). Attention should be paid to the stable situation of the South Korean port of Busan which was incessantly ranked $5^{\text {th }}$ until 2013 and which is taking the $6^{\text {th }}$ place now. 
China has over 2.000 seaports of which 130 serve the world fleet. As more than $90 \%$ of the trade exchange takes place by sea, the shipbuilding industry has been developing rapidly including the expansion of container terminals. The largest container ports include: Dalian, Guangzhou, Lianyungang, Ningbo, Qingdao, Shenzhen, Shanghai, Tianjin, Yingkou and Xiamen. Figure shows the handling volume in Chinese container ports in 2016.

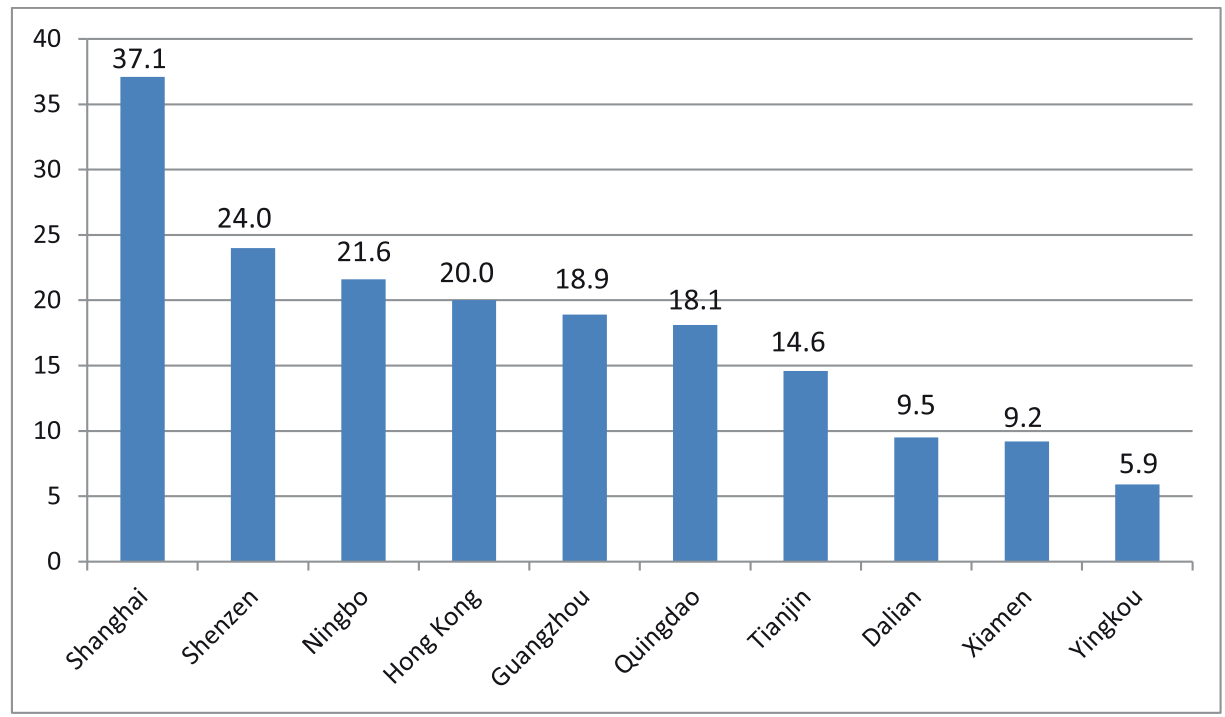

Figure 1. Container transshipments in largest Chinese seaports in 2016 (millions of TEUs) Source: (Statista, 2018)

Shanghai has been the largest container port in the world since 2010. Transshipments in the port have been growing each year since 2000 - increasing by 80.600 TEUs in the period 2010-2016 only. The hub, consisting of several interconnected ports, is constantly expanded and upgraded. It owes its rapid development chiefly to the construction of the Yangshan Deep Water port which was opened in 2005 and which can handle the largest container ships in the world (Figure 2). This port is located on an island and it is connected to the mainland by the Donghai bridge which is $32.5 \mathrm{~km}$ long (one of the longest bridges in the world). In 2018 the next stage of the port's expansion consisting in testing a fully automated container terminal was started. The terminal will be equipped with an automatic management system, automatic loading and unloading devices, including 26 bridge cranes, 120 gantry cranes and 130 AGVs. The expansion of the Yangshan Deep Water Port will have been fully completed in 2020. The total budget of this project is over 500 billion yuans. 


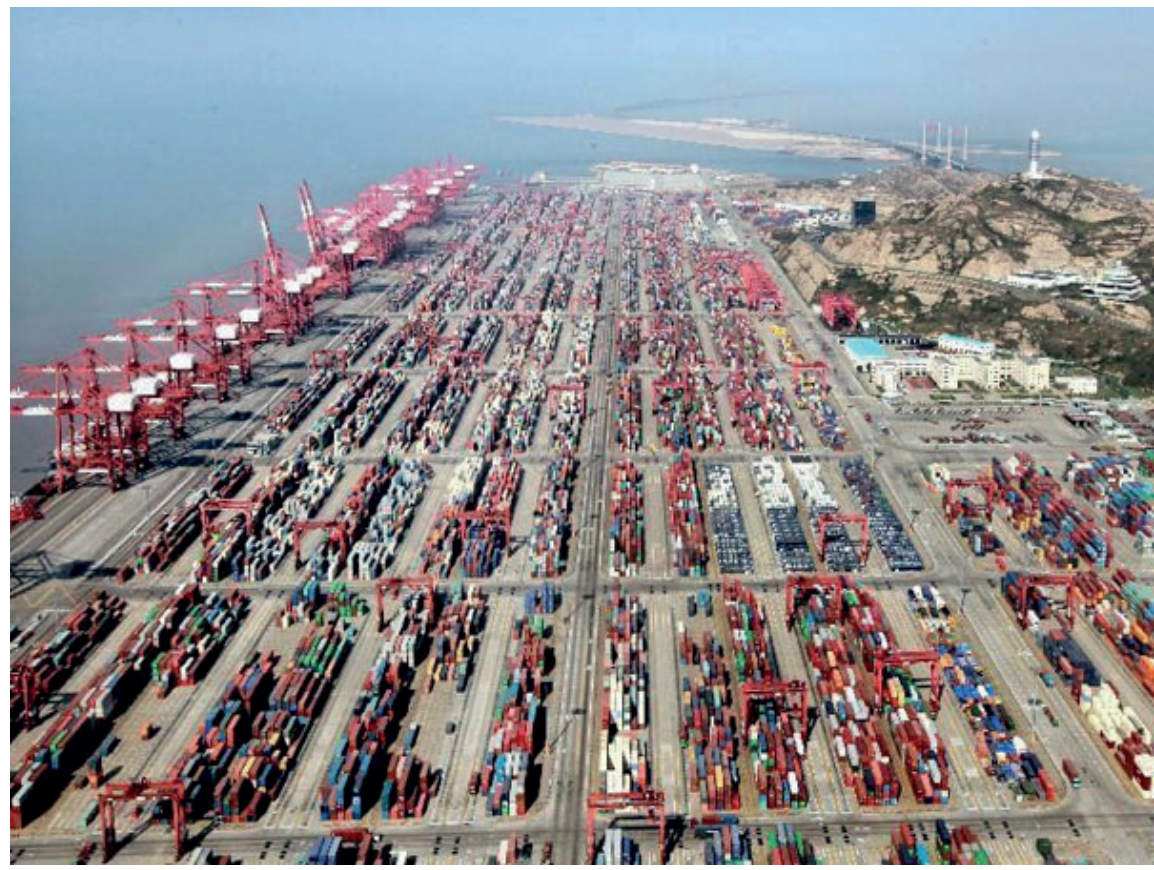

Figure 2. Yangshan Deep Water Port Source: (topchinatravel, 2018)

The first fully automated container terminal in Asia operating since 2017 is the terminal located in the eastern port of Qingdao which is operating round the clock (Qingdao, 2018).

The rapid development of China's economy took place in the late 1970s owing to its marketisation and opening out to the world. It was the gradual liberalization of foreign trade, establishment of special economic zones, business facilitation for foreign entities as well as relocation of manufacturing operations to this country due to the low cost of manufacture that were the main reasons contributing to the development of maritime container transport.

Japan has 1020 ports, including 22 special-purpose ports, 106 main ports and 892 local ports. The main container ports include ports located in Tokyo, Yokohama, Nagoya, Kobe and Osaka. In 2011, the Japanese government designated strategic hubs for international sea-going vessels combining the ports of Yokohama, Tokyo and Kawasaki into the so-called Keihin ports and the ports of Osaka and Kobe into the so-called Hanshin ports. Moreover, a hub comprising the ports of Osaka, Kobe, Sakai-Semboku and Amagasaki-Nishinomiya-Ashiya is located in the Gulf of Osaka.

Government measures aimed at increasing transshipments in Japanese ports include state subsidies and loans to equip ports with specialized facilities and devices so as to compete with other Asian ports in the future, especially with the port of Singapore and the Korean port of Busan which have been increasing their handling volumes significantly thanks to the support received from their 
governments (nikkei, 2018). The implementation of this policy as of 2010 resulted in an increase in the container traffic by $2.4 \%$ in 2016 - for the first time in 2 years (joc, 2018).

4.7 million TEUs were transshipped at the largest Japanese port in Tokyo in 2016 (Figure 3). The port of Kobe and the port of Yokohama handled 2.8 million TEUs, the port in Nagoya 2.7 million TEUs, and the port of Osaka 2.2 million TEUs.

The top ten Japanese container ports in 2016 included also Hakata, Naha, Shimizu, Kitakyushu and Tomakomai which handled 966.300 TEUs, 541.500 TEUs, 517.300 TEUs, 571.300 TEUs, and 316.700 TEUs, respectively. Hiroshima, which was ranked $11^{\text {th }}$, handled 257.100 TEUs (joc, 2018).

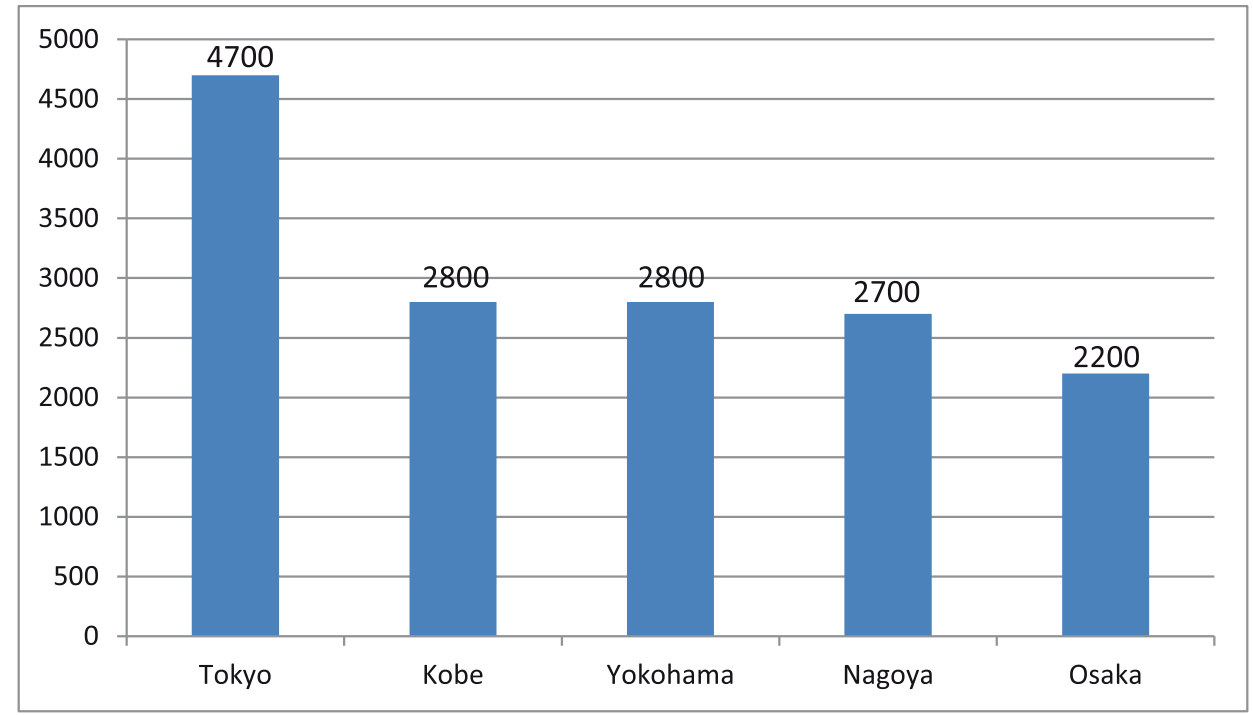

Figure 3. Container transshipments in largest Japanese ports in 2016 (millions of TEUs) Source: (joc, 2018)

South Korea is among the highly industrialized countries with robust industrial sectors in the area of new technologies. The country is ranked $13^{\text {th }}$ on the list of the largest economic powers in the world. The Korean economy is included among economies that are most open to business. According to the Index of Economic Freedom (IEF) the country was ranked $5^{\text {th }}$ in Asia and $23^{\text {rd }}$ in the world in 2016 (joc, 2018). The main ports of South Korea are: Busan, Incheon, Mokpho, Musan, Ulsan and Phohang.

The priority of the South Korean government was to have a logistic centre with a global status. Duty free zones were established in ports which made it possible to transform the main Korean container ports into logistic centres of Northeast Asia. As a result, a new port in Busan was created in 2011 with the annual handing capacity of over 8 million containers and which is managed by the public corporation, Busan Port Authority (BPA).

The port of Busan handles $80 \%$ of container transshipments in the country, and its share in international trade with respect to South Korean ports exceeds 75\%. 
The location on the south-eastern end of the Korean peninsula and the deepwater and tidal conditions have made it the largest port of Korea and the sixth largest port in the world. In 2016, the container handling volume at the port of Busan was 194.600 TEUs. The port has introduced the Landlord Port system whereby terminals are leased to shipowners and transport companies. It is planned to develop the port further with the target of having 60 container terminals by 2020 . The port of Busan has four fully equipped modern ports - the North Port, the South Port, the Gamcheon Port and the Dadaepo Port - an international passenger terminal and six container terminals. Owing to the long coastline $(26.8 \mathrm{~km})$ it is possible to moor 169 ships at the same time and handle 91 million tonnes of freight per year. The port's advanced loading/unloading equipment, such as high-speed container cranes that can handle the largest container ships in the world, provides the capacity to serve as many as 130 ships per day (Port of Busan, 2018).

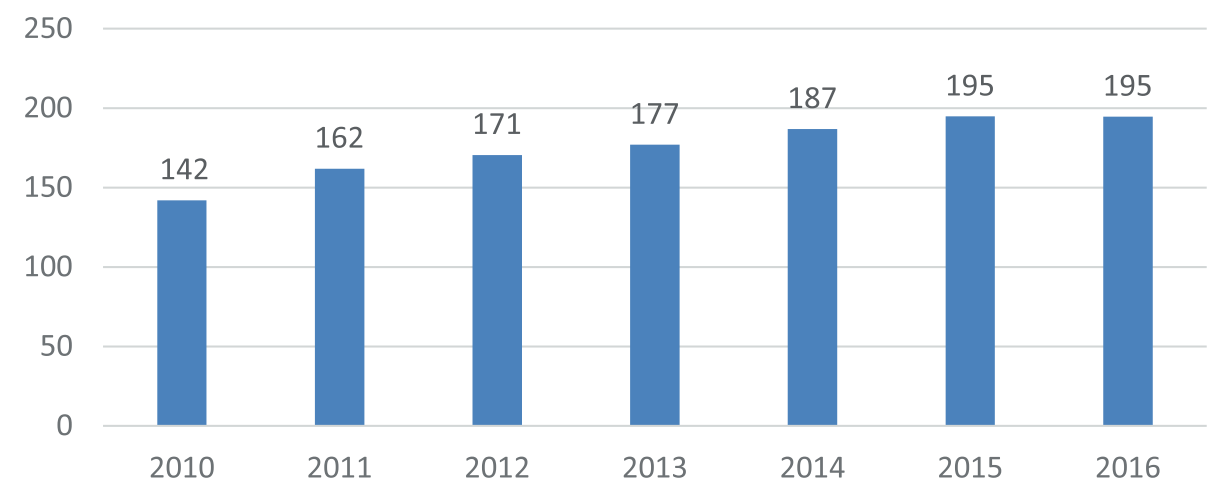

Figure 4. The number of containers handled at the port of Busan in the period 2010-2016 (thousands of TEUs)

Source: (Mardep, 2018)

The Indian Peninsula has one of the largest coastlines in the world, extending for over $7.500 \mathrm{~km}$, accommodating around 200 Indian ports including 13 largest ones. The major ports handle over $70 \%$ of the whole freight traffic.

The most important international container ports are in Jawaharlal Nehru, Chennai, V.O. Chidambaranar, Calcutta and Cochin. The ports of Jawaharlal Nehru and Chennai account for $80 \%$ of the container traffic in India.

The largest container port in India - JNPT Jawaharlal Nehru handled 4.5 million TEUs in 2016, ultimately by 2020 it will be capable of handling 10 million TEUs per year. The JNPT container terminal is equipped with the latest devices that meet all the international standards. It also has excellent rail and road connections with the rest of the country (jnport, 2018). The terminal has been upgraded recently and additionally equipped with modern cranes and other port facilities which has increased its throughput capacity by approximately $12 \%$. 
The port of Chennai which is located in the south-eastern part of the country is one of the oldest ports in India. It is well linked with the rest of the world and it is called the Gateway of South India. The port has railways approx. $40 \mathrm{~km}$ long and 8 sidings to handle loads such as granite or grain. The Chennai Container Terminal (CCT) is adapted to serve deep draft ships. Containers are handled using a railway platform with two lines $725 \mathrm{~m}$ long. The wharf is equipped with seven cranes, 18 bridge cranes and six reach stackers (chennaiport, 2018; worldportsource, 2018).

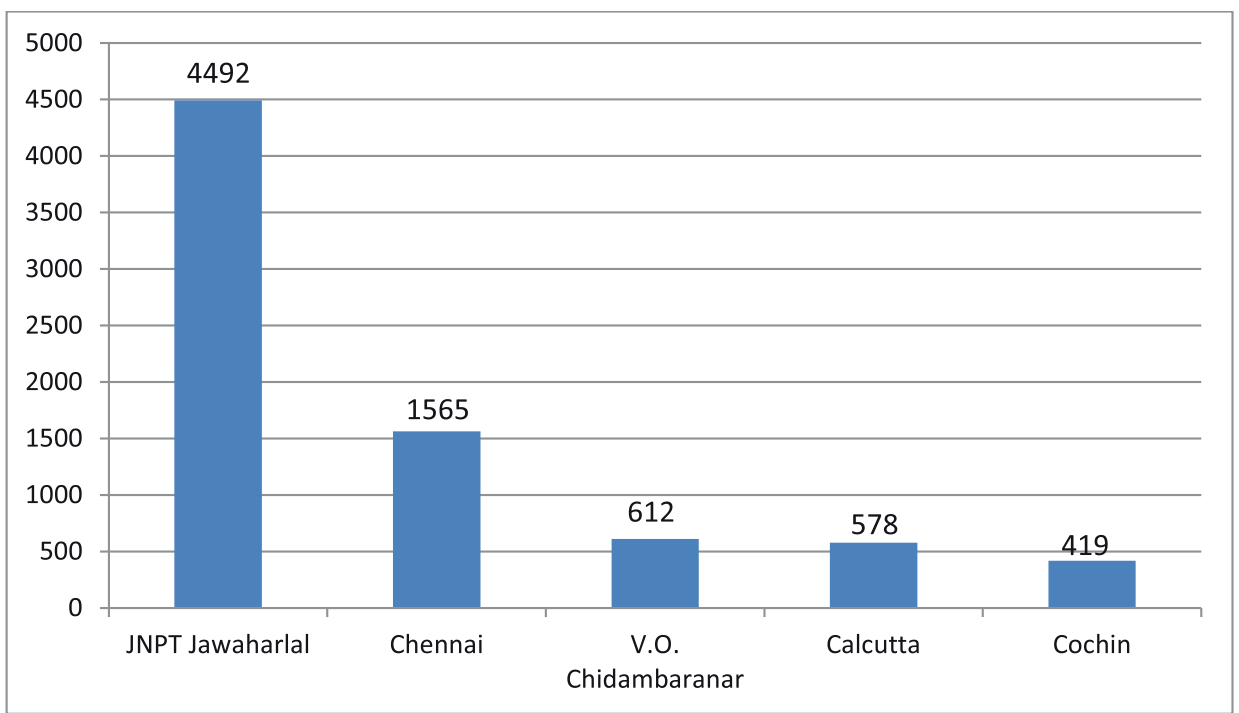

Figure 5. Container transshipments in largest Indian ports in 2016 (thousands of TEUs) Source: (India Ports Association, 2018)

The activities of major Indian ports are based on trust funds managed by the government. Nonetheless, many local ports are in private hands or they are leased from the state.

\section{Container transport in China, Japan, South Korea and India}

The dynamic development of the maritime trade in recent years is owed to China which is the largest importer of crude oil in the world, and moreover, the commodities imported to this country include huge amounts of copper, iron ore and coal. In 2016, the Chinese shipyards were the third largest shipbuilder in the world (following Greece and Japan) receiving 50\% of the global orders along with Germany and Singapore. It should also be noted that in 2016 three economies only, i.e. South Korea, China and Japan built $92 \%$ of the world tonnage, with Korea having the largest share of $38.1 \%$ (unctad, 2018). 
China has 5206 ships with a DWT of 1000 tonnes and more (Maritime Executive, 2018). The total tonnage of Chinese container ships more than doubled in the period 1990 to 2010 - reaching a DWT of 32,833,000 at that time. A further increase in the DWT up to 38,099 was noted in the period 2011-2016. Table 2 shows the growth of the Chinese container ship fleet in size (DWT).

Table 2. Chinese fleet by vessel type in 1990-2016 (thousands of DWT)

\begin{tabular}{|l|l|r|r|r|}
\hline Country/Province & \multicolumn{1}{|c|}{ Ship } & $1990-2000$ & $2001-2010$ & $2011-2016$ \\
\hline \multirow{5}{*}{ China } & Oil tankers & 35071 & 63008 & 73627 \\
\cline { 2 - 5 } & Bulk carriers & 110111 & 149446 & 253792 \\
\cline { 2 - 5 } & General cargo & 77835 & 63472 & 26308 \\
\cline { 2 - 5 } & Container ships & 15758 & 32833 & 38099 \\
\cline { 2 - 5 } & Other & 10839 & 11076 & 27694 \\
\cline { 2 - 5 } & Total & 249614 & 319835 & 419520 \\
\hline \multirow{5}{*}{ Hong Kong } & Oil tankers & 12690 & 101247 & 157856 \\
\cline { 2 - 5 } & Bulk carriers & 102160 & 316753 & 474396 \\
\cline { 2 - 5 } & General cargo & 7332 & 24340 & 15727 \\
\cline { 2 - 5 } & Container ships & 9453 & 49480 & 116721 \\
\cline { 2 - 5 } & Other & 1859 & 5066 & 20937 \\
\cline { 2 - 5 } & Total & 133494 & 496886 & 785637 \\
\hline \multirow{5}{*}{ Taiwan } & Oil tankers & 9752 & 14487 & 2460 \\
\cline { 2 - 5 } & Bulk carriers & 26733 & 27092 & 14806 \\
\cline { 2 - 5 } & General cargo & 1584 & 1610 & 822 \\
\cline { 2 - 5 } & Container ships & 33354 & 54470 & 26169 \\
\hline & Other & 10470 & 7161 \\
\cline { 2 - 5 } & Total & 322 & & 920 \\
\hline
\end{tabular}

Source: (UNCTAD, 2017)

By the end of 2015, one of the most important maritime container shipping companies on the Chinese market was China Shipping Container Lines (CSCL), established in 1997 and based in Shanghai, which had international container agencies and terminals worldwide, and which provided a full range of intermodal freight shipment services supported by electronic data exchange. Due to the reduced demand for container transport in 2013, which triggered a wave of mergers and acquisitions, CSCL initiated talks on establishing cooperation with the state-owned Cosco Group. In late December 2015, both parties announced a formal merger, establishing Cosco Containers Lines, renamed later to Cosco Shipping Development (unctadstst, 2018).

The largest shipping operations in Japan in terms of both exports and imports of goods are carried out by sea due to the island location of the country. The major shipping routes in the world include those connecting Japan with the United States, Australia, Europe and the Persian Gulf (UNCTAD, 2017).

Japanese container ships had the largest tonnage in 1990-2000, 13.6 million DWT at that time, while a regular decline was observed in the later period (Table 3 ). It should be assumed that the factors contributing to this situation included but 
were not limited to natural disasters that affected Japan (earthquakes, tsunamis) as well as the global economic crisis.

Table 3. Japanese fleet by vessel type in 1990-2016 (thousands of DWT)

\begin{tabular}{|l|c|c|c|}
\hline \multicolumn{1}{|c|}{ Ship } & $1990-2000$ & $2001-2010$ & $2011-2016$ \\
\hline Oil tankers & 10684 & 21123 & 5226 \\
\hline Bulk carriers & 74485 & 92576 & 76259 \\
\hline General cargo & 12420 & 13720 & 9579 \\
\hline Container ships & 13648 & 11440 & 7545 \\
\hline Other & 8920 & 8049 & 11632 \\
\hline Total & 120157 & 146907 & 110240 \\
\hline
\end{tabular}

Source: (UNCTAD, 2017)

The Japanese government allocated funds to build environmentally friendly new generation ultra-large container vessels (ULCVs) to maintain and improve the quality of services and reinforce both the efficiency and cost competitiveness of its fleet on the international market. Moreover, Japanese companies (Mitsui OSK Lines, Nippon Yusen and others) intend to make investments in the development of unmanned, remotely controlled cargo ships. The first Japanese unmanned vessel will appear on ocean waters after 2035 (The Guardian, 2018).

The Republic of Korea has 1907 vessels in total, of which 89 are container ships (indexmundi, 2018). The total tonnage of Korean container ships was regularly declining. It fell by more than half in the period 1990 to 2016. Table 4 shows the growth of the Korean container ship fleet in size (DWT).

Table 4. Korean fleet by vessel type in 1990-2016 (thousands of DWT)

\begin{tabular}{|l|c|c|c|}
\hline \multicolumn{1}{|c|}{ Ship } & $1990-2000$ & $2001-2010$ & $2011-2016$ \\
\hline Oil tankers & 10684 & 21123 & 5226 \\
\hline Bulk carriers & 74485 & 92576 & 76259 \\
\hline General cargo & 12420 & 13720 & 9579 \\
\hline Container ships & 13648 & 11440 & 7545 \\
\hline Other & 8920 & 8049 & 11632 \\
\hline Total & 120157 & 146907 & 110240 \\
\hline
\end{tabular}

Source: (UNCTAD, 2017)

Shipping companies in the Republic of Korea are mostly fragmented. At the same time, the long stagnation in the container transport market and intense competition have created a crisis among South Korean shipping companies. In 2017 Hanjin Shipping - the seventh largest container carrier in the world went bankrupt. The Korea Shipping Partnership - a coalition of 14 South Korean container carriers was established in order to strengthen the domestic maritime shipping sector and, most of all, make the Korean companies credible to their existing foreign trade partners. The companies forming the partnership were: Hyundai Merchant Marine, CK Line, Dongjin Shipping, Doowoo Shipping, Dong Young Shipping, Hansung Line, Heung-A Shipping, KMTC, Namsung Shipping, Mr. Continental Shipping, 
Mr. Ocean, Sinokor Shipping, SM Line and Taiyoung Shipping. The objective of the alliance is to increase the competitiveness of the domestic container transport sector, inter alia, by opening new joint connections, cooperation in developing the fleet, providing joint services at international terminals, and consultations with the aim to reduce the operating costs.

Approximately 95\% of the Indian trade is carried out by sea. At the end of 2015, the Indian fleet consisted of 1246 vessels with a total DWT of 15.3 million. However, the Indian fleet needs urgently to be replaced, since as many as $42 \%$ of the vessels are more than 20 years old, and $12 \%$ of them are between 15 and 19 years old (The Economic Times, 2017).

The tonnage of Indian container ships is regularly growing. In the period 2001-2010, it went up to 1.876.000 DWT, more than 2.5 times more than, for example, in the period 1990-2000, when the DWT was 730.000. The tonnage continued to grow in the years 2011-2016 - reaching the DWT of 2.056.000 (Table 5).

Table 5. Indian fleet by vessel type in 1990-2016 (thousands of DWT)

\begin{tabular}{|l|r|r|r|}
\hline \multicolumn{1}{|c|}{ Ship } & 1990-2000 & $2001-2010$ & 2011-2016 \\
\hline Oil tankers & 43444 & 72332 & 49995 \\
\hline Bulk carriers & 55579 & 39633 & 29622 \\
\hline General cargo & 11769 & 4489 & 6017 \\
\hline Container ships & 730 & 1876 & 2056 \\
\hline Other & 8060 & 9392 & 8026 \\
\hline Total & 119578 & 127721 & 95716 \\
\hline
\end{tabular}

Source: UNCTAD (2017)

The growing cargo container transshipment and shipping volumes in India have been triggered by liberalization of the domestic transport market. It is also the incentives introduced by the government in the form of tax exemptions that have a positive effect on the development, extension and maintenance of sea ports.

\section{Port infrastructure funding in China, Japan, South Korea and India}

The main institutions financing the transport infrastructure development in the Europe-Asia maritime corridors are the Asian Development Bank, the European Bank for Reconstruction and Development, the World Bank and the European Investment Bank.

The Asian Development Bank (ADB) was established in the Far East in 1960 with a vision to support economic growth and regional cooperation in this part of the world. It associates 48 Asian countries and 19 countries from outside the region. The headquarters of the Bank are in Manila, Philippines, while the main branches are based in Bangladesh, India, Nepal, Pakistan and Vanatau (ADB, 2018). The bank lends funds to governments, national banks and also to state-owned enterprises and private individuals for specific purposes. ADB invests mainly in the industry, agriculture, energy, transport and telecommunications. The bank manages special funds: 
- Asian Development Fund;

- Special Technical Assistance Fund;

- Special Japanese Fund.

The Asian Infrastructure Investment Bank is a new institution established on the initiative of China, which started to operate in January 2016. It was founded to provide financial support to build the infrastructure in Asia and beyond. This bank is the response of the emerging economies, led by China, to the financial institutions dominated chiefly by the United States. The member states include but are not limited to China (26.5\% of the shares), India (7.7\%) and the Republic of Korea (3.6\%). Some countries, like e.g. Japan, have decided not to join the Asian Investment and Infrastructure Bank (Asian Infrastructure Investment Bank, 2018).

The World Bank provides support through direct financing of investment projects, participation in financial consortia and providing guarantees for countries eligible to the aid programme. The amount of USD 1.2 billion was provided for the Indian infrastructure development including upgrading and extension of roads and ports as part of the loan of USD 4.3 billion granted by the World Bank. Many infrastructure projects in India are financed by loans from the World Bank and the Asian Development Bank (biznes.pl, 2018).

The European Bank for Reconstruction and Development (EBRD) co-financed transport infrastructure projects in the period 1991-2007 providing over EUR 5 billion, while the total value of completed investment projects amounted to approx. EUR 17 million. The European Bank for Reconstruction and Development actively supports also public-private partnership projects, which are an alternative to the limited possibility of financing infrastructure investment projects from public funds. By the end of 2006, the value of 138 PPP projects in transport co-financed by the EBRD amounted to EUR 4.7 billion, of which $18.3 \%$ was private capital. In 2016, the bank allocated a record amount of EUR 9.4 billion to implement 378 investment projects in over 30 emerging economies (EBRD, 2018).

The European Investment Bank (EIB) supports projects that contribute to increasing the regional integration. Its participation cannot exceed 50\% of the investment cost, and the minimum direct support in the form of loans is EUR 25 million. In addition to financial aspects, the bank also provides consulting services addressed to the authorities of the EU Member States and institutions, in particular, in the field of development and use of PPP instruments. The countries qualified by the EIB for financing in 2014-2020 included China, India and South Korea (EIB, 2018).

\section{Conclusions}

The level of transport and handling volumes in seaports depends chiefly on the global economic phenomena. In 2009, which was the year starting the period of global economic slowdown, global maritime container shipments decreased by more than $10 \%$ (123 million TEUs) (Obserwator Morski, 2018). It was also at the beginning of 2013 that the largest shipowners serving the most important sea routes between Asia and Europe suspended operation of approx. $6 \%$ of the world 
container fleet (Obserwator Morski, 2018). At that time the CKYHE maritime alliance reduced the traffic of container vessels on lines representing almost $17 \%$ of its transport capacity. No recovery in the sea transport was noted in 2014 despite the expectations - although the demand for this type of transport grew, however, the emergence of new vessels with a capacity exceeding 10.000 TEUs on the global market was the reason why the supply increased. Heavy-lift vessels have become most effective in financial terms, particularly in view of the fact that the freight rates in container transport are relatively low.

It should be noted that this market is highly competitive, with almost a constant surplus of the supply of transport services over the demand. This surplus was reduced with the opening of the Panama Canal which made the Panamax container ships redundant. This led to massive scrapping of vessels of this type, which included seven-year old Indian Rickmers, which was the youngest ship ever to be scrapped. The forecasts of Maersk Line predict that the demand for services and container ships will be balanced by 2022. The Boston Consulting Group is of a different opinion assuming deterioration (probably doubling) of excess capacity over the demand by 2020 (joc, 2017). When considering which of these forecasts will come true, one should take into account the weaker balance between supply and demand, due to the prices for container handling or the declining trade volume between China and the United States. However, the main reason for the global uncertainty are the customs duties imposed by the US on China for new goods, and the retaliation tariffs that will be introduced for American goods by their trading partners. The maritime container transport should continue to develop because of the price discipline implemented by carriers manifesting itself in the fleet consolidation, the growing trade in South America, maritime transport of containers at shorter distances or the expected GDP growth in developed economies in the forthcoming years. It is a fact that the world container fleet is growing, for example, in 2016 it grew by 1.1\% compared to the preceding year (joc, 2018).

The largest sea trade region is definitely Asia. In 2016, Asian sea ports reported 4.1 billion tonnes of cargo shipments and 6.3 billion tonnes of unloading operations, which accounted for $61 \%$ of all such operations (the remaining continents recorded less than half of these volumes) (UNCTAD, n.d.). At the same time, Southeast Asia is one of the most important container regions in the world, which is why both China, as well as Japan, South Korea and India are striving to increase the importance of their ports in global transshipments. They are the main driving force behind the development of the country's economy, affecting the entire logistics system of supply chains and networks.

\section{References}

adb (2018). Available from www.adb.org/About/History [Accessed 3 March 2018].

Asian Infrastructure Investment Bank (2018). Available from https://www.aiib.org/en/index. html [Accessed 7 February 2018]. biznes.pl (2018). Available from http://biznes.pl/magazyny/finanse/pozyczka-z-bs-na-wsparciebankow-i-rozwoj-infrastr,3038062,magazyn-detal.html [Accessed 5 March 2018]. chennaiport (2018). Available from www.chennaiport.gov.in [Accessed 28 March 2018]. CSO (2017), Statystyka międzynarodowa [International Statistics], CSO, Warsaw. 
European Bank for Reconstruction and Development (2018). Available from http://www. ebrd.com/home [Accessed 3 March 2018].

European Investment Bank (2018). Available from http://www.eib.org/ [Accessed 18 February 2018].

hal (2018). Available from https://hal.archives-ouvertes.fr/file/index/docid/918674/filename/O-PCA-052-RF-FFP-Hidekazu_ITOH structural_changes_in_port_cargo_flow_ distribution_in_asian_container_port_systems; Top 50 World Container Ports. World Shipping Council [Accessed 20 January 2018].

indexmundi (2018). Available from www.indexmundi.com/south_korea/merchant_marine. html [Accessed 5 February 2018].

Indian Ports Association (2018). Available from http://ipa.nic.in//showimg.cshtml? ID =803 [Accessed 28 March 2018].

Japanese ports (2018), Government to help enhance competitiveness. NIKKEI Asian Review. Available from http://asia.nikkei.com/Politics-Economy/Policy-Politics/Govern- ment to- help-enhance-competitiveness [Accessed 20 March 2018].

jnport (2018). Available from www.jnport.gov.in/JNPCT.aspx [Accessed 28 March 2018].

joc (2018). Available from https://www.joc.com/ [Accessed 3 March 2018].

mardep (2018). Available from www.mardep.gov.hk/en/publication/pdf/portstat_2_y_b5.pdf [Accessed 20 March 2018].

Maritime Executive (2018). Available from https://www.maritime-executive.com/article/ the-global-fleet-revealed\#gs.R=efd_U [Accessed 2 February 2018].

Mindur, L. (Ed.) (2014), Technologie transportowe [Transport Technologies], Scientific Publishing House of the Institute for Sustainable Technologies - PIB, Warsaw-Radom.

Mindur, M. (Ed.) (2017), Logistyka. Nauka, badania, rozwój [Logistics. Science, Research, Development], Scientific Publishing House of the Institute for Sustainable Technologies - PIB, Warsaw-Radom.

Obserwator Morski (2018). Available from www.obserwator-morski.pl/artykuly/246/Slab y-rynek-przewozow-kontenerow [Accessed 25 February 2018].

Port of Busan (2018). Available from https://www.ship-technology.com/projects/portofbusan/ [Accessed 20 March 2018].

Qingdao (2018). Available from www.qingdao-port.com/en/gywm_1_1.jsp [Accessed 20 March 2018].

Statista (2018), The statistical portal. Available from http://www.statista.com/statistics/268670/ leading-seaports-for-container-handling-in-china/ [Accessed 20 January 2018].

Support the Guardian (2018). Available from https://www.theguardian.com/world/2017/ jun/08/japanese-self-driving-cargo-ships-within-decade [Accessed 5 February 2018].

The Economic Times (2017). Available from https:/economictimes.indiatimes.com/industry/ transportation/shipping-/- transport/economic-survey-2016india-in-urgent-need-to-inc rease-shipping-fleet/articleshow/51154574.cms [Accessed 5 November 2017].

topchinatravel (n.d.). Available from www.topchinatravel.com/china-attractions/ yangshan-deep-water-port.htm [Accessed 5 November 2017].

unctad (n.d.). Available from http://unctad.org/en/PublicationsLibrary/tdstat42_en.pdf [Accessed 5 November 2017].

unctadstst (2017). Available from http://unctadstst. unctad.org/wds/TableView/tableView. aspx [Accessed 5 December 2017].

United Nations Conference on trade and Development UNCTAD (2017). Available from http://unctadstst.unctad.org/wds/ [Accessed 5 December 2017]. vesselfinder (2018). Available from www.vesselfinder.com/pl/vessels/OOCL-HONGKONG-IMO-9776171-MMSI-477333500 [Accessed 3 April 2018].

worldportsource (2018). Available from www.worldportsource.com/ports/commerce/ IND_Port_of_Chennai_495.php [Accessed 28 March 2018]. 
worldshipping (2018). Available from www.worldshipping.org/about-the-industry/ global-trade/top-50-world-container-ports [Accessed 20 January 2018].

\section{Corresponding author}

Leszek Mindur can be contacted at: lmindur@vp.pl 